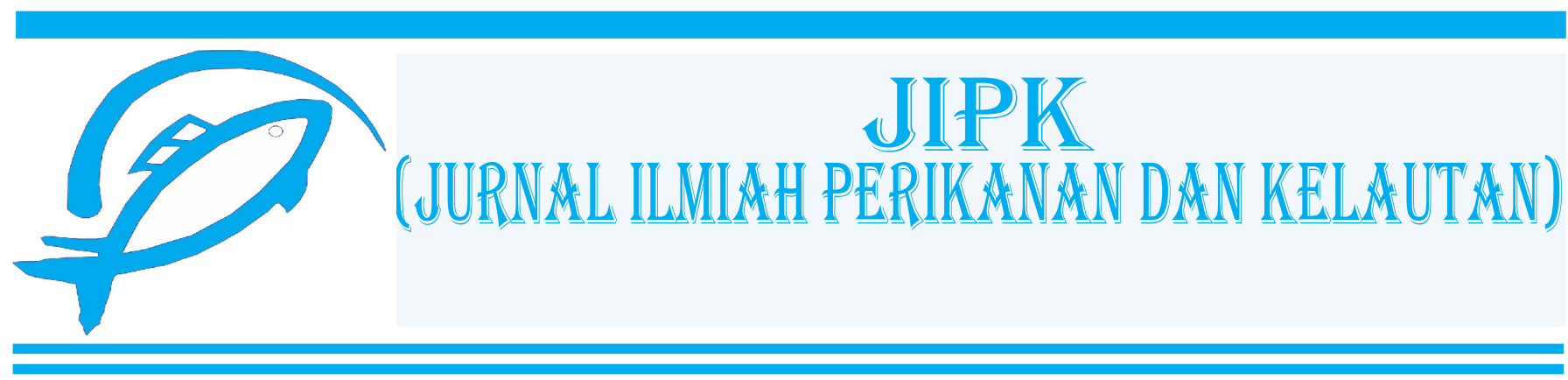

Research Article

\title{
The Length-Weight Relationship and Condition Factors of Bullet Tuna Landed at the Tanjung Luar Fishing Port, Indonesia
}

\author{
Evron Asrial ${ }^{*}$ (D), Yasir Arapat ${ }^{1}$, Usma Kurniawan Hadi ${ }^{2}$, Kalih L.A.T.T.W.S ${ }^{1}$, Mita Ayu Liliyanti ${ }^{2}$, \\ Erwin Rosadi ${ }^{3}$, Ruly Isfatul Khasanah ${ }^{4}$, and Ishani Nelunika Rathnayake
}

${ }^{1}$ Department of Fisheries Resources Utilization, Faculty of Fishery, University of 45 Mataram, West Nusa Tenggara. Indonesia ${ }^{2}$ Department of Aquaculture, Faculty of Fishery, University of 45 Mataram, West Nusa Tenggara. Indonesia

${ }^{3}$ Department of Capture Fiheries, Faculty of Fishery and Marine, University of Lambung Mangkurat, Banjarbaru, South Kalimantan. Indonesia

${ }^{4}$ Department of Marine Science, Faculty of Science and Technology, Islamic State University of Sunan Ampel, Surabaya, East Java. Indonesia

${ }^{5}$ Department of Fisheries and Aquaculture, Faculty of Fisheries \& Marine Sciences and Technology, University of Ruhuna, Matara. Sri Lanka

\section{OPEN ACCESS}

\section{$\underline{\text { ARTICLE INFO }}$}

Received: September 13, 2020

Accepted: January 05, 2021

Published: March 30, 2021

*) Corresponding author:

E-mail: evronasrial81@gmail.com

Keywords:

BLT

Broodstock

Maturity

Transitional Season

This is an open access article under the CC BY-NC-ND license (http://creativecommons.org/licenses/by-nc-nd/4.0/)

\begin{abstract}
Bullet tuna (Auxis rochei Risso 1810) or tongkol lisong (Indonesian) is important for human consumption and health as well as an income source for fishers and coastal communities. Its utilization problems are over exploitation, catch domination by immature groups, and the threatened stock security of the bullet tuna (BLT). This research aimed to determine the status of the prospective parent of bullet tuna caught in the Lesser Sunda region, particularly from the Alas Strait to the Indian Ocean, West Nusa Tenggara (WNT). Meanwhile, the data were collected from July to September 2020 ( $2^{\text {nd }}$ transitional season) at the Tanjung Luar Fishing Port, East Lombok and a dependent survey method was adopted with sampling, interview, observation, and documentation techniques. Fork length and body weight data were used to estimate the length and weight relationship, growth pattern, condition factor, fishagegroup, and catchworth. The primary and secondary datawere processed quantitatively using several equations. The growth pattern of bullet tuna was minor allometric $(\mathrm{b}=2.875)$, worth selling $(\mathrm{K}>1.00)$, and the majority was adult fish or mature group. The LWR model is $\mathrm{BW}=0.0209 \mathrm{FL}^{2.875}$. This condition indicates the bullet tuna is worth catching (FLc/FLm $>1.0=94.77 \%)$ and worth spawning, so that it is eligible to be a potential broodstock candidate to support a sustainable management of BLT fisheries. Furthermore, fishers have applied the code of conduct for responsible fisheries (CCRF) in supporting the sustainable development goals.
\end{abstract}

Cite this as: Asrial, E., Arapat, Y., Hadi, U. K., Kalih, L. A. T. T. W. S., Liliyanti, M. A., Rosadi, E., Khasanah, R. I., \& Rathnayake, I. N. (2021). The Length-Weight Relationship and Condition Factors of Bullet Tuna Landed at the Tanjung Luar Fishing Port, Indonesia. Jurnal Ilmiah Perikanan dan Kelautan, 13(1):1-10. http://doi.org/10.20473/jipk.v13i1.22585 


\section{Introduction}

Tuna neritic fish resources are very popular and favoured by most Indonesians and the world community. It is open resource to everyone to catch and utilize in waters around the world, including the coastal areas of the Indian Ocean. Furthermore, tuna neritic were exploited by some countries in the Indian Ocean including Indonesia, Thailand, Sri Lanka, India, and Pakistan (IOTC, 2018) as well as Australia (Griffiths et al., 2019).

Human has used tuna neritic for consumption and health purposes because of its high nutritional content, which consists of $69.40 \%$ water, $1.50 \%$ fat, $25.00 \%$ protein, and $0.03 \%$ carbohydrates (Nisa, 2018). Another content is Omega-3, which is useful to reduce the risk of Age Macular Disease (AMD) or eyes disease caused by aging. It also maintains the health of the digestive tract and the heart, as well as to develop cognitive capacity of individual. Furthermore, the iron content in neritic tuna helps to prevent anemia.

Meanwhile, Indonesia is one of the major countries in the world that produces bullet tuna caught from the Indian Ocean including the coastal waters of the Lesser Sunda region. One potential producer in this region is Tanjung Luar in Lombok Timur Regency. Furthermore, the landing of bullet tuna is done at the Tanjung Luar Fishing Port which also functions as an oligopsony and auction market.

The bullet tuna (Auxis rochei Risso 1810) or tongkol lisong (Indonesian) is one of many species managed by the Indian Ocean Tuna Commission (IOTC) which is the target for most fishers in Tanjung Luar. It is caught using a troll line in the coastal water areas of the Indian Ocean and the southern part of the Alas Strait. However, it has reached the stage of over exploitation $(\mathrm{E}=0.60)$ in the Indian Ocean, south of East Java (Agustina and Rochman, 2019). Furthermore, the caught bullet tuna is dominated by fish groups that have never experienced maturation $(L c<L m)$ and are classified as immature (Asrial et al., 2020a). This condition is the same as the bullet tuna caught by fishers in the Indian Ocean, south of East Java (Agustina and Rochman, 2019). Meanwhile, the activity of catching bullet tuna in these waters (Sumatra, Java, Sumbawa) threatens the security of bullet tuna (BLT) reserves and their populations (Asrial et al., 2020a).

Study on the biological parameters of bullet tuna in the Indonesian waters has been carried out by Widodo et al. (2011), Setyadji et al. (2013), Widodo and Satria (2013), Noegroho et al. (2013), Widodo et al. (2014), Noegroho and Chodrijah (2015), Tampubolon et al.
(2016) and Kurniawan et al. (2019). The similar study on species of neritic tuna groups in the coastal waters of the Indian Ocean, south of West Nusa Tenggara(WNT) has been carried out on kawakawa (Euthynnus affinis Cantor, 1849) (Agustina et al., 2018; Amri et al., 2018; Ekawaty and Jatmiko, 2018; Fathurriadi et al., 2020) and bullet tuna (Asrial et al., 2020a). The study of kawakawa species in southern WNT is related to parameters of growth (Agustina et al., 2018; Fathurriadi et al., 2020), reproductive and spawning seasons (Amri et al., 2018), and reproductive biology (Ekawaty and Jatmiko, 2018).

A study of the bullet tuna (Auxis rochei) in the Indian Ocean on the southern coast of WNT was conducted by Asrial et al. (2020a) regarding its landed on Cemplung Beach (south of Sumbawa Island). Therefore, this study aimed to determine the availability status of bullet tuna potential broodstock through growth parameters analysis. The growth attributes consist of growth pattern $(b)$, condition factor $(K)$, fork length and body weight relationship ( $L W R$ ), fish age group, and fish worth catching $(F L c / F L m)$. This study examines the growth, population status and biological condition of bullet tuna resources landed at the Tanjung Luar Fishing Port, the largest fisheries center in southern WNT. The aim is to estimate the composition and status of eligibility (fit to catch, fit for sale, fit for spawning) and age group of tuna bullet resources based on data fork length and body weight.

\section{Materials and Methods}

\subsection{Location and Period of Study}

This research was carried out at the Tanjung Luar Fishing Port which is located in Tanjung Luar Village, Keruak District, Lombok Timur Regency (Figure 1) and the grace period was 3 (three) months from JulySeptember 2020 during the second transitional season period. Sampling was conducted by surveyors every Saturday/Sunday (4-8 times a month), each amounting to between 41-93 individuals/sampling. Overall, the sampling was 12 times for 784 individuals which was obtained from twelve different troll liners (24 fishers). The samples of bullet tuna fish only come from the fishers that live in Tanjung Luar Village. They caught bullet tuna in the southern coastal waters of the Alas Strait (located between Lombok Island and Sumbawa Island) and the Indian Ocean (south of Lombok Island) (Figure 1).

\subsection{Materials and Equipments}

The main target fish sample was the bullet tuna, 


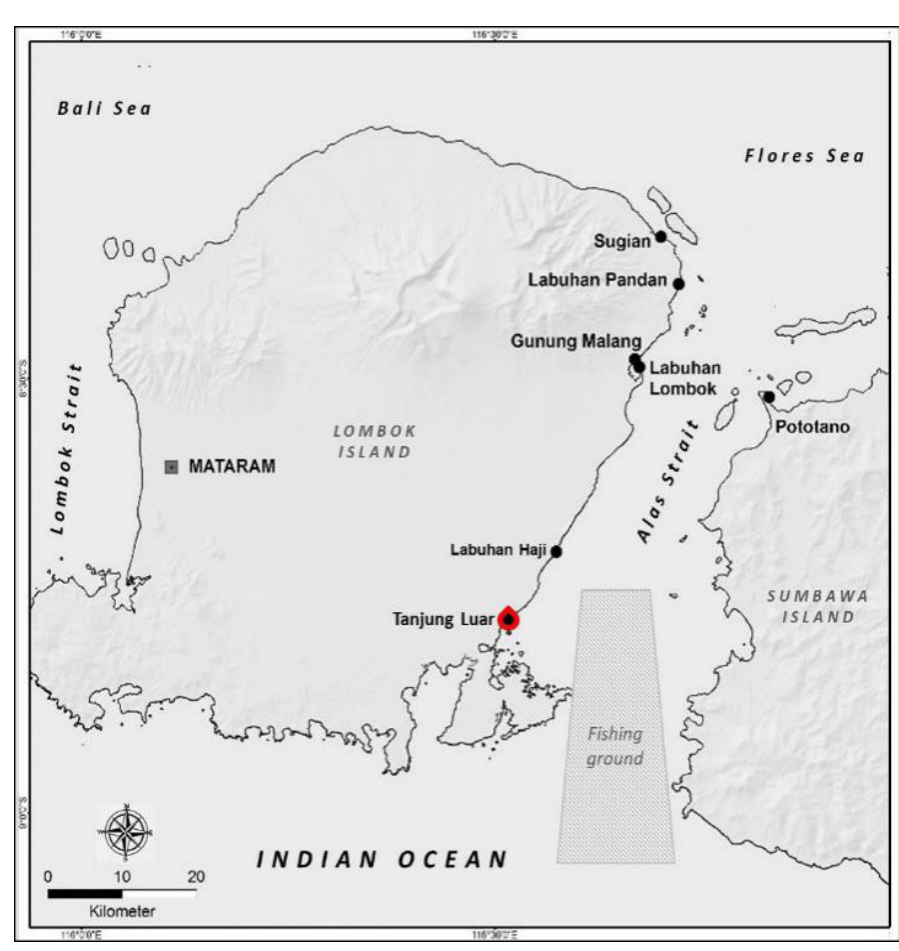

Figure 1. Map of research location and fishing ground

which was caught in the southern coastal waters of the Alas Strait and the Indian Ocean, and landed on the Tanjung Luar Fishing Port, East Lombok Regency. The fish samples (784 individuals) caught using troll lines and wooden boats were obtained from fishers who dropped them off at the fishing port. Fish sampling had been carried out randomly at the fishing port and the selection of fish samples was entrusted to the fishers. The sample fish were packed in containers (an airtight cool box) and transported from the fishing port to the Fishery Faculty, University of 45 Mataram by motorcycle in 2.0 hours. The main equipment used for identification consists of an iron ruler (accuracy of $1.0 \mathrm{~mm}$ ), a scale (accuracy of $1.0 \mathrm{~g}$ ), stationery, and a work table.

\subsection{Data Colleted}

Data were collected using the dependent survey method with sampling, interviews, documentation, and observation (measurement, weighing, observation) techniques. The data of fork length (FL) and total weight (BW) were obtained from observing, and recording the results of measurement, and weighing of each sample. FL data is the dimension of the fish from the tip of the mouth to the base of the tail. Measuring and weighing all sample fish activities have been carried out from 01 August to 30 September 2020 at the Basic Laboratory of the Fishery Faculty, University of 45 Mataram.

\subsection{Data Analysis}

The feasibility of the utilization of bullet tuna was approached by analyzing the attributes of growth patterns and condition factors. These attributes showed a correlation with the feasibility of exploiting fish resources, indicating that they are unique and different from other types of animals.

\subsubsection{Growth Pattern}

The data for fork length and total weight were also used to calculate growth patterns. The formula is (Ndimele et al., 2010), where $B W=$ body weight (g), $F L=$ fork length $(\mathrm{cm}), a=$ intercept, and $b=$ growth exponent. Natural logarithm (ln) was also used because the tuna fish live in water areas that are uncontrollable or naturally without human intervention. This will lead to zero line, which means that someday neritic tuna will die (Fahurriadi et al., 2020). Growth pattern $(b)$ and condition factors $(K)$ can indicate the age group of fish (Asrial et al., 2020b). The value of $b$ in $L W R$ and the growth pattern equation have the same value. Models/ equations of tuna bullet growth patterns are shown in the section on the results of data processing.

Furthermore, the growth pattern of bullet tuna is the coefficient value of the independent variable, namely the fork length coefficient. Its status is divided into 3 (three) categories as follows: (a) $b<3.0$ : minor allometric, i.e., the growth rate of the weight is slower than the length (thin body shape), (b) $b=3.0$ : isometric, i.e., the growth rate of the weight and length are the same (slim body shape), and (c) $b>3.0$ : major allometric, i.e., the growth rate of weight is faster than the length (plump body shape).

\subsubsection{Length and Weight Relationship (LWR)}

The attributes of the model are needed to determine the growth rate of the fish length and weight (Asrial and Rosadi, 2017). Furthermore, the calculation uses the length and weight relationship (LWR) approach and the parameter is estimated using a simple regression meth- od application in excel format. The formula is $B W=\mathrm{aFL}^{\mathrm{b}}$ (Ndimele et al., 2010; Kurniawan et al., 2019) where: body weight (g), $F L=$ fork length $(\mathrm{cm})$, a $=$ intercept, and $b=$ growth exponent. The sample data of length and weight of members of the fish population represent / indicate the age group of the fish. Thus, to estimate fish age groups, an LWR chart is used that is compared with a fish growth chart (Sigmoid chart). In this study, the age groups of fish are classified into groups of young fish (immature), adult fish (mature), and old fish.

\subsubsection{Condition Factors}

The condition factor $(K)$ is an economic approach 
that indicates the feasibility of the fish trade (Effendie, 2002). In fisheries science, this factor is used to compare the "condition" and the "obesity" or "welfare" of fish (Egbal et al., 2011). Therefore, $K$ is part of the growth indicator and is used as a standard/reference forassessing the performance of fisheries and resource management. Measurement and analysis were carried out on each individual fish sample to obtain the distribution and portion of the value.

Furthermore, $K$ is used as a standard indication of the aquatic environmental condition (Asrial et al., 2020a), especially regarding the fertility of waters as a source of fish feed. This is similar to the opinion of Fagade (1979) who reported that the condition factor is an index of growth disturbance and feeding intensity. Therefore, the condition factor describes the obesity of the fish body (Effendie, 2002). It also provides an estimation phenomenon of broodstock availability based on the age group of fish in the waters, which is used to estimate the reproductive cycle of fish (Welcomme (1979) and Effendie (2002). Meanwhile, the condition factor value of bullet tuna in this study is estimated by the formula: where: $K=$ condition factor, $B W=$ body weight $(\mathrm{g}), F L=$ fork length $(\mathrm{cm}), a=$ Intercept and $b=$ coefficient (Effendie, 2002).

In order to confirm the closeness of the relationship between the two parameters ( $b$ value), a t-test was performed (Effendie, 2002) with the formulation: where: $b=$ the calculated value of the ratio of length and weight of fish, and $S b=$ standard deviation. The hypothesis used in this study is $\mathrm{H}_{0}=$ isometric $(b=3.00)$ and $\mathrm{H}_{1}$ $=$ allometric $(b \neq 3.00)$. The next step is to carry out the $\mathrm{t}$-test so that the t-statistic value is known, which is then compared to the t-table value. Decisions that can be taken refer to the following criteria

a. if the t-stat value is greater than the t-table ( $t$-value $>$ $\mathrm{t}$-table), then reject $\mathrm{H}_{0}(\mathrm{~b} \neq 3)$ and the growth pattern is major allometric $(b>3)$ or minor allometric $(b<3)$.

b. if the t-stat value is smaller than the t-table value, then reject $\mathrm{H}_{1}(\mathrm{~b}=3)$, and the growth pattern is isometric $(b=3)$.

To determine the status, the conditions are as follows (Fathurriadi et al., 2020):

1) $\mathrm{K}=1.00-2.00$ : the fish body is less flattened, already fleshy, and have high economic value, such that they are suitable to be caught and traded, and as prospective broodstock.

2) $\mathrm{K}=2.00-3.00$ : the fish body is flat, quote fleshy, and of normal economic value such that it is not yet suitable for fishing and trading, and as a prospective broodstock, and

3) $\mathrm{K}=3.00-4.00:$ The body of the fish is slightly flattened, not yet fleshy, and has low economic value, therefore, it is not suitable to be caught and traded, and as a prospective broodstock.

The condition factors value also describes the fertility of the waters related to the availability and adequacy of feed. The categories are as follows:

1) $K>1.0:$ the feed available in the waters is very sufficient to support activities, growth, and reproduction.

2) $K=1.0:$ the availability of feed in the waters is only enough for movement and body growth.

3) $\mathrm{K}<1.0$ : the feed available in the waters is sufficient to survive.

\section{Results and Discussion}

\subsection{Frequency of Fork Length and Body Weight}

The identifications result of the bullet tuna samples (784 individuals) showed a total length (TL) of 21.00$33.30 \mathrm{~cm} /$ ind. (mean $=27.24 \mathrm{~cm} /$ ind.) and fork length (FL) of $20.00-32.20 \mathrm{~cm} /$ ind. (mean $=26.29 \mathrm{~cm} /$ ind.) (Figure 2). Meanwhile, the body weight (BW) is in the range of $120.00-433.00 \mathrm{~g} / \mathrm{ind}$. with an average of 258.27 g/ind. (Figure 3).

Based on Figure 2 and Figure 3, it can be estimated that the number of mature bullets tuna is greater than the immature ones. The number of mature bullet tuna for attributes of $\mathrm{FL} \geq 24.63 \mathrm{~cm} / \mathrm{ind}$. (Tampubolon et al., $2017)$ and BW ( $\geq 212.00 \mathrm{~g} / \mathrm{ind}$.) are 596 ind. (76.02\%) and 579 ind. (73.85\%) respectively. This condition indicates that the bullet tuna broodstock population in the waters is sufficient for regeneration in supporting the reserves/stocks security of bullet tuna resources and the sustainability of bullet tuna fisheries management.

Based on data of the fork length (FLc) of the caught bullet tuna compared with the length data for the bullet tuna fork at first maturity (FLm), it can be known the number of bullet tuna that is worth catching. Fish are deemed fit to be caught if FLc is longer than FLm, or $F L c / F L m>1.0$. The number of bullet tuna that was worth catching was identical to the number of mature bullet tuna. In Tanjung Luar Fishing Port, there were 743 individuals $(94.77 \%)$ of bullet tuna that were fit to catch. Meanwhile, only 41 individuals $(5.23 \%)$ of bullet tuna were not yet fit to catch (Figure 4). 


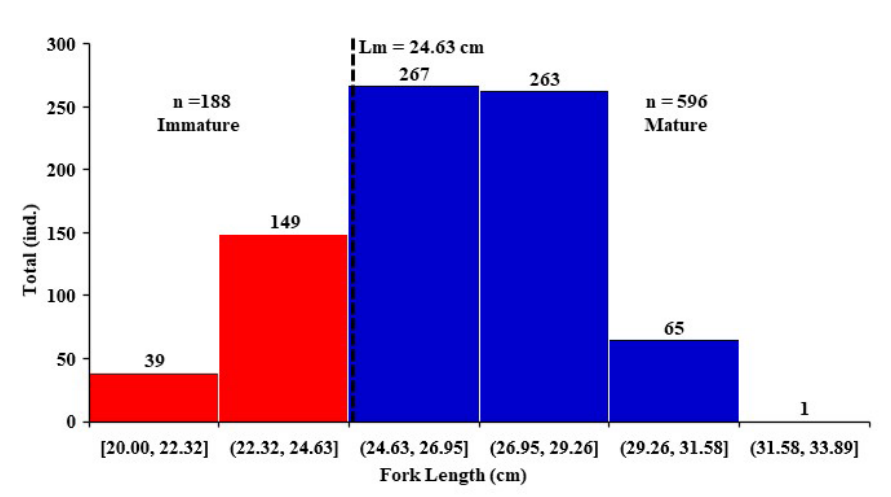

Figure 2. Fork length (FL) class frequency of bullet tuna

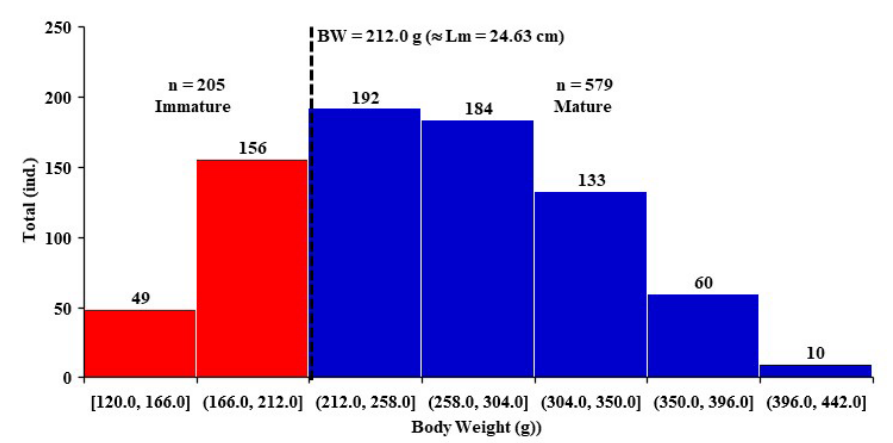

Figure 3. Body weight (BW) class frequency of bullet tuna

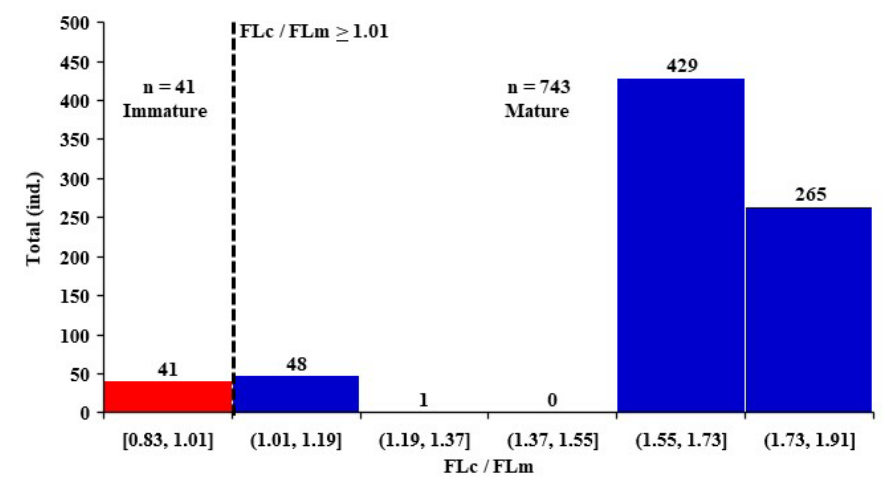

Figure 4. Number of bullet tuna is worth catching (FLc / $\mathrm{FLm}>1.01)$

\subsection{Growth Pattern}

The results of logarithmic data processing for analysis of fork length and body weight relationship (LWR) using simple regression obtained the values of correlation $(r)$, determination $\left(R^{2}\right)$, Adjusted R Square $\left(A d j . R^{2}\right)$, and Standard Error $(S E)$ as well as the growth pattern of tuna bullets (Table 1). Regarding growth parameters, the growth pattern of bullet tuna landed at Tanjung Luar Fishing Port was a representation of the FL coefficient (b) which was 2.875 (Table 1).

The value of $r=97.40 \%$ indicates a very close relationship ( $\mathrm{r}>80 \%$ ) between the FL and BW attributes.
Meanwhile, the value of $\mathrm{R}^{2}=94.87 \%$ means that $\mathrm{FL}$ is very strong $\left(\mathrm{R}^{2}>80 \%\right)$ affects / determines BW. The values of $r$ and $R^{2}$ are close to $1(100.00 \%)$ which means when FL gets longer, then BW gets heavier. Value of Adj. $R^{2}$ is $94.86 \%$ meaning that the samples have very high abilities (Adj. $\mathrm{R}^{2}>50.00 \%$ ) to find answers in their own population. Meanwhile, $\mathrm{SE}=5.84 \%$ means that the model error that occurs is still acceptable or tolerated (SE $<25.00 \%)$. It can be concluded that the model formed is very accurate and suitable for forecasting $\left(\mathrm{R}^{2}>60 \%\right)$.

The mathematical model is a positive model, where each additional one unit of fork length will increase the body weight by the value of the fork length coefficient. Thus, its growth pattern status is minor allometric $(b<$ 3.0) or thin body shape. This status is consistent with the body shape of the bullet tuna which is stream line (torpedo shape) and as a fast-swimming fish. For this reason, it requires a lot of energy obtained from the conversion of food consumed by bullet tuna, which results in inhibition of the body's growth activity of bullet tuna.

\subsection{Analysis of $L W R$}

The analysis of the fork length and body weight relationship (LWR) on 784 ind. bullet tuna obtain the equation is (Figure 5), which means the growth pattern is minor allometric $(b=2.785)$. This equation can be used to estimate the ideal fish body shape namely is ideal body shape. By using this equation, it is known that the ideal value of the body of a bullet tuna is between 0.8-1.2 and the average is 1.0.

The left image shows the LWR conditions during the study (Figure 5). It is assumed that bullet tuna is landed at Tanjung Luar Fishing Port, most of the bullet tuna samples were in the mature group when juxtaposed and compared with a fish growth chart (sigmoid graph).

The fish age group can be estimated through fork length data of fish, this includes bullet tuna, using the fork length approach. The immature bullet tuna caught was at a fork length of about $25 \mathrm{~cm}$ (Expósito, 2015). Tampubolon et al. (2016) reported that bullet tuna first maturity (mature group) is at a fork length of $24.63 \mathrm{~cm} /$ ind. In this study, there were 784 ind. samples with a fork length distribution of 20.0-32.2 cm/ind. Based on these two opinions, bullet tuna landed at Tanjung Luar Fishing Port includes: (a) 222 individuals (28.32\%) adolescents age group (immature) and (b) 562 individuals (71.68\%) adults age group (mature) (Figure 6). 


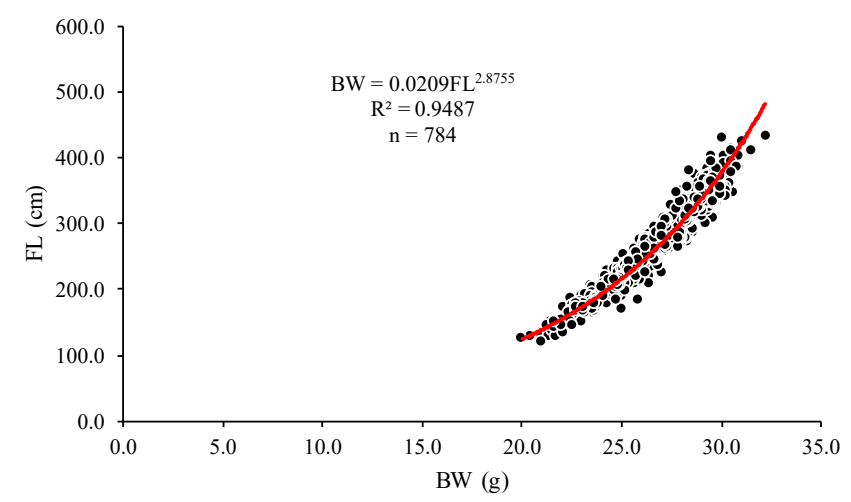

Figure 5. FL and BW relationship (LWR) of bullet tuna

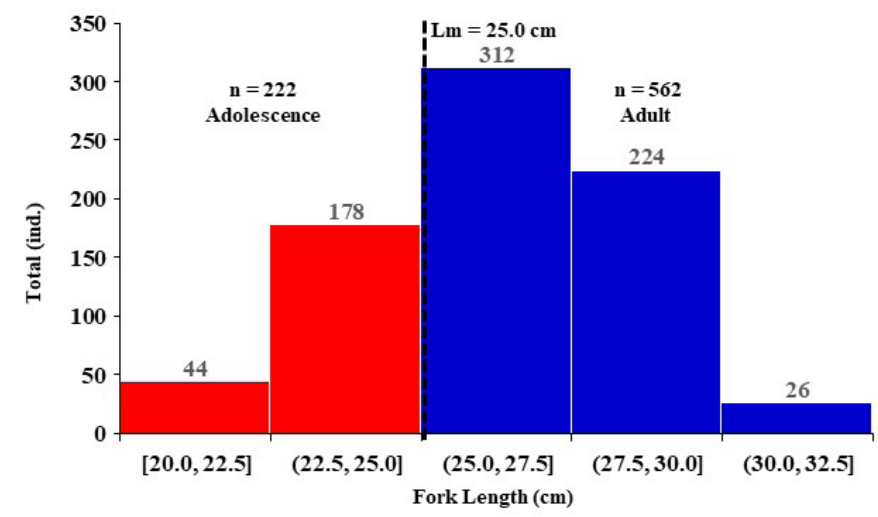

Figure 6. Age group of bullet tuna

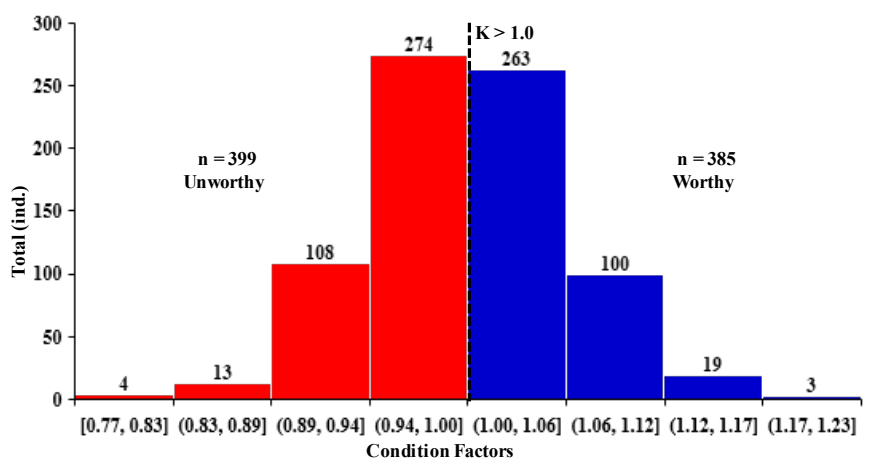

Figure 7. Condition factor $(\mathrm{K})$ of bullet tuna

\subsection{Condition Factors}

The results of the t-test on the value of $(\alpha=0.05)$, obtained the $t_{\text {stat }}$ value $=5.2053$, and the $t_{\text {table }}$ value $(0.05$; $782)=1.645$, or the t-stat value bigger than the t-table value. Thus, $\mathrm{H}_{0}$ is rejected and $\mathrm{H}_{1}$ is accepted, which means the growth pattern of the bullet tuna is minor allometric. Minor allometric, which means that the fork length (FL) growth rate is faster than the body weight (BW) growth rate. Based on the results of the t-test, the equation used to estimate the condition factor for bullet tuna is . Estimation based on this equation, obtained the value of $K_{\text {minimum }}=0.77, K_{\text {maximum }}=1.21$ and $K_{\text {average }}=1.00$.
Table 1. LWR anlaysis of bullet tuna

\begin{tabular}{lcc}
\hline Attribute & Unit & Score \\
\hline Correlation $(\mathrm{r})$ & $\%$ & 97.40 \\
Determination $\left(\mathrm{R}^{2}\right)$ & $\%$ & 94.87 \\
Adjusted $\mathrm{R}^{2}$ & $\%$ & 94.86 \\
Standard Error & $\%$ & 5.84 \\
Observation & Individuals & 784 \\
Intercept & - & -3.867 \\
ln FL coefficient & - & 2.875 \\
Model & - & $B W=0.0209+$ \\
& & $2.875 F L$ \\
Growth Pattern & - & Minor Allometric \\
\hline
\end{tabular}

The estimation results of the mean value of the condition factor $(K>1.0)$ were 385 individuals $(49.11 \%)$ (Figure 7). As many as 399 individuals (50.89\%) of bullet tuna were already fleshy and had moderate economic value, however, they were unworthy as broodstock candidates $(K<1.0)$. This is a sign that almost any bullet tuna landed from Tanjung Luar is already fleshy and has high economic value, therefore it is suitable to be caught, traded, and is feasible to be prepared to become a prospective fish parent. Referring to the value of $K_{\text {average }}$ $=1.00$, the body shape of the bullet tuna landing at Tanjung Luar Fishing Port is ideal.

The condition factor for bullet tuna landed at Tanjung Luar Fishing Port indicates that the quality of the waters in the bullet tuna fishing ground has supported the life and growth of bullet tuna. This means that the waters are very fertile because they are able to provide natural food in very adequate and sufficient quality and quantity to support the processes and results of the life activities of bullet tuna.

The season of bullet tuna fishing only lasts from July to September every year, and the peak of fishing activity and production at Tanjung Luar Fishing Port occurs during August. Meanwhile, there is only bullet tuna species caught by fishers in the Alas Strait and the Indian Ocean coastal waters. They caught the bullet tuna using trolline from early morning (around 03:00 a.m.) to 9:00 a.m. (one-day fishing trip). Some of their catch is sold by fishers's wives to collectors and some others to retailers at the Tanjung Luar fish market. Furthermore, the bullet tuna caught by Tanjung Luar fishers is 3-4 ind/ $\mathrm{kg}$ or $317.46 \mathrm{~g} / \mathrm{ind}$. Neritic tuna fisheries activities by Tanjung Luar fishers are classified as environmentally friendly due to the use of trolling lines which are very selective about the size of the fish. 
JIPK. Volume 13 No 1. April 2021 / The Length-Weight Relationship and Condition Factors of Bullet Tuna Landed....

Table 2. Composition of the fork length of bullet tuna in the Indian Ocean

\begin{tabular}{lcccl}
\hline Indian Ocean & Type of Fishing Gear & $\begin{array}{c}\text { Range } \\
(\mathbf{c m} / \mathbf{i n d})\end{array}$ & $\begin{array}{c}\text { Modus } \\
\mathbf{( c m /} \\
\mathbf{i n d})\end{array}$ & \multicolumn{1}{c}{ References } \\
\hline West Sumatra & Purse seine, seine, troll line & $11.0-42.0$ & $25-26$ & Noegroho \& Chodrijah (2015) \\
$\begin{array}{l}\text { North \& West Suma- } \\
\text { tra }\end{array}$ & Purse seine & $19.0-38.0$ & - & Salmarika et al. (2018) \\
$\begin{array}{l}\text { South of East Java } \\
\text { South Sumbawa }\end{array}$ & Purse seine & $13.3-26.0$ & 20.22 & Agustina \& Rochman (2019) \\
South Lombok & Surface longline & $21.0-29.2$ & 23.50 & Asrial et al. (2020) \\
\hline & Troll line & $20.0-32.2$ & 26.16 & This study \\
\hline
\end{tabular}

The habitat for bullet tuna in the Indian Ocean is spread from western Sumatra, southern Java, to the southern part of the Lesser Sunda region. Its fork length is still longer than those from the Indian Ocean in other part of Indonesia (Table 2). Additionally, the difference in size is due to the variation in the type of gear used, season, and/or fishing ground (beaches waters, small islands waters, high seas).

Bullet tuna from Tanjung Luar is mostly fork length in class $26.0 \mathrm{~cm} /$ ind and ranges from 20.00 to $32.20 \mathrm{~cm}$ $/$ ind (mean $=26.16 \mathrm{~cm} /$ ind). Their first maturity $(\mathrm{FLm})$ was estimated at the fork length of $24.63 \mathrm{~cm} /$ ind (Tampubolon et al., 2017) and $24.60 \mathrm{~cm} /$ ind (Noegroho and Chodrijah, 2015). Referring to the FLm value, the majority landed in Tanjung Luar Fishing Port has reached a first maturity level (FLm $>24.63 \mathrm{~cm} /$ ind), which is a total of 596 individuals $(76,02 \%)$. Meanwhile, 188 $(23.98 \%)$ of the bullet tuna were thought to have been immature. Furthermore, the bullet tuna landed in Cemplung Beach (Sumbawa) (Asrial et al., 2020a) and Prigi, East Java (Agustina and Rochman, 2019) were dominated by immature groups ( $\mathrm{FL}<25.0 \mathrm{~cm} /$ ind.).

The difference in FL size may occur due to the variation of fishing gear used by Tanjung Luar (troll line) fishers with Labangka (longline), and Prigi (purse seine). This estimate is in line with the opinion of Asrial et al. (2020a) who stated that the differences in size are due to the variation in fishing gear and areas. Furthermore, tonda is a very selective and environmentally friendly fishing gear. However, the longline and purse seines are not very selective and environmentally friendly because the line (hook) and mesh are small so that the length of the fish caught $(L c)$ is smaller than the length at first maturity $(\mathrm{Lm})$.

The status of the bullet tuna growth pattern from Tanjung Luar is minor allometric. This is the same as those from the western coastal waters of Sumatra (Kurniawan et al., 2019), the Mediterranean, and Turkey (Kahraman et al., 2011). However, it is different from the waters of the west coast of Sumatra (Tampubolon et al., 2016), the Makassar Strait (Kantun et al., 2019), and southern Sumbawa (Asrial et al., 2020a) which have major allometric status $(b>3.0)$. Moreover, large fish changes shape to be more elongated, indicating better nutritional status or fitness than the smaller size in minor allometric status (Expósito, 2015). Their growth pattern will streamline the body of the neritic tuna and improve its fitness so that it becomes a fast swimmer. This situation is very beneficial for neritic tuna since it helps to avoid predators.

The condition factor $(K)$ attribute is an important part of the fish growth parameter because it is useful to estimate fish population (Effendie, 2002), which also predicts maturity. In addition, when the condition factor is associated with the maturity of the bullet tuna from Tanjung Luar, the gonad maturation at $K>1.00$ isidentical to $\mathrm{FL}>24.63 \mathrm{~cm}$. Therefore, the matured bullet tuna reached 385 individuals $(49.11 \%)$. Referring to Fathurriadi (2020), the value of $K=1.0-2.0$ describes the fish with an economically and biologically viable status. Meanwhile, $\mathrm{K}$ values between 1-3 imply that the fish body is less flattened (Effendie, 2002), which is identical to the fat size. The condition factor is used to estimate the "condition", "obesity" or "welfare" of fish (Egbal et al., 2011). This indicates that the fish is fleshy and/or in their mature gonads period, which is classified as an adult. This statement is in line with the opinion of Ndimele et al. (2010) that the condition factor is also a useful index for monitoring the feeding intensity, age, and growth rate of fish. Furthermore, the feeding intensity and growth rate will explain the age groups of fish which are divided into juvenile, immature, mature, and old groups. 


\section{Conclusion}

The utilization of fisheries resources is part of its conservation, which consists of protection and preservation. The conservation is a form of sustainable fisheries management which is the same with the resources exploited by the fishers of Tanjung Luar, Lombok Timur Regency. Furthermore, management activities were carried out by the community, consisting of fishers/producers and traders/consumers. It is managed without the involvement, intervention, and incentives of stake holders (bureaucrats, technocrats, and private companies). Based on the results, it is concluded that the resources and reserves of the bullet tuna population are in a safe condition, which is dominated by the adult age group and immature group, and with the proper status as potential broodstock, and the utilization of bullet tuna resources is classified as environmentally friendly, and its management has implemented the Code of Conduct for Responsible Fisheries (CCRF) to support fisheries sustainability as outlined in the SDGs (sustainable development goals).

\section{Acknowledgements}

This research activity starts from the preparation of proposals to the publication of research results, assisted and supported by the parties. Many thanks to the Foundation of 45 Mataram (Yayasan 45 Mataram) and Fishery Faculty, University of 45 Mataram for supporting this research and publication. The authors are grateful to the fishers and all parties in Tanjung Luar that assisted the research team in collecting sample fish and identification. The authors are also grateful to Andi Firmansyah Kaplale, Fauzah Andriani, Resty Ainul Mustika Ayu, and Ridwan, students of the Fishery Faculty, University of 45 Mataram, that helped with the identification of the sample fish.

\section{Author's Contributions}

The authors have contributed very well, from designing research to checking the draft final of the manuscript before it is sent to journal managers. Evron Asrial; designed and carried out surveys, monitored data processing and analysis activities, also wrote research reports and scientific publication manuscripts. Yasir Arapat and Usma Kurniawan Hadi; compiled, tabulated, and separated the data, especially the bullet tuna sampling results. Erwin Rosadi, Rusmin Nuryadin and L.A.T.T.W.S. Kalih; carried out quantitative data processing and wrote down the resume. Ruly Isfatul Khasanah and Ishani Nelunika Rathnayake; analyzed the results of data processing. Meanwhile, Mita Ayu
Liliyanti and Naning Dwi Sulystyaningsih; revised and perfected sentences and vocabulary in the publication manuscript.

\section{Conflict of Interest}

The authors state that they do not have competing interests and conflicts of interest among them.

\section{Funding Information}

This research and publication was funded by Ministry of Research and Higher Education through the "Bidikmisi Program" scholarship fund, the Foundation of 45 Mataram, the University of 45 Mataram and the authors.

\section{References}

Agustina, M., Jatmiko, I., \& Sulistyaningsih, R. K. (2018). Growth pattern and condition factor of kawakawa, Euthynnus affinis (Cantor 1849) in Tanjung Luar Waters West Nusa Tenggara. BAWAL. 10 (3):179-185.

Agustina, M., \& Rochman, F. (2019). Population parameters of bullet tuna (Auxis rochei Risso, 1810) in Prigi waters and its surroundings. In XVI Annual National Seminar on 2019 Fisheries and Marine Research Results. pp. 219-226.

Amri, K., Nora, F. A., Ernaningsih, D., \& Hidayat, T. (2018). Reproduksi dan musim pemijahan tongkol komo (Euthynnus affinis) berdasarkan monsun dan suhu permukaan laut di Samudera Hindia Selatan Jawa-Nusa Tenggara. BAWAL, 10(2):155-167.

Asrial, E., \& Rosadi, E. (2017). Silverside fish (Atherinomorus lacunosus) in Banggai waters, Indonesia: Almost extinct? In $14^{\text {th }}$ ADRI International Conference and Call for Papers (pp 89-95). Denpasar, Indonesia: ADRI.

Asrial, E., Rosadi, E., \& Fathurriadi. (2020a). Utilization, growth, and population of bullet tuna (Auxis rochei Risso 1810) in Indian Ocean southern Sumbawa. Indonesian Journal of Aquaculture and Fisheries, 2(1):19-28.

Asrial, E., Rosadi, E., Hamid, Ichsan, M., Khasanah, R. I., Sulystyaningsih, N. D., Sumiwi, A. D., \& Khalisah, N. (2020b). Growth and Population Parameters of Panulirus penicillatus and Panulirus homarus in Labangka Tidal Waters, Indonesia. Jurnal Ilmiah Perikanan dan Kelautan, 12(2):214223.

Effendie, M.I. (2002). Biologi Perikanan. Yogyakarta: Yayasan Pustaka Nusatama 
Egbal, O. A, Ali, M. E., \& Aziz, A. A. (2011). Lengthweight relationships and condition factors of six fish species in Atbara River and Khashm el-Girba Reservoir, Sudan. International Journal of Agriculture Sciences, 3(1):65-70.

Ekawaty, R., \& Jatmiko, I. (2018). Reproductive biology of kawakawa, Euthynnus affinis (Cantor, 1849) in Eastern Indian Ocean. Jurnal Iktiologi Indonesia, 18(3):199-208.

Expósito, P. M. (2015). Assessing the atmospheric oscillations effects on the biology of the bullet tuna (Auxis rochei) and its possible linkage with global warming. Thesis. Faro: University of Algarve.

Fagade, S. O. (1979). Observations on the biology of two species of tilapia from the Lagos Lagoon, Nigeria. Bulletin de l'Institut français d'Afrique noire, 41A(3):629-653.

Fathurriadi, Asrial, E., \& Rizal, L.S. (2020). Eligibility status Euthynnus affinis (Cantor, 1849) from Lombok Strait and Indian Ocean southern Sumbawa. Indonesian Journal of Aquaculture and Fisheries, 2(1):1-8.

Griffiths, S. P., Zischke, M.T., van der Velde, T., \& Fry, G. C. (2019). Reproductive biology and estimates of length and age atmaturityof longtail tuna (Thunnus tonggol) in Australian waters based on histological assessment. Marine and Freshwater Research, CSIRO Publishing. 12p.

Kahraman, A. E., Göktürk, D., \& Karakulak, F. S. (2011). Age and growth of bullet tuna, Auxis rochei (Risso), from the Turkish Mediterranean coasts. African Journal of Biotechnology, 10(15):3009-3013.

Kantun, W., Cahyono, I., \& Arsana, W. S. (2019). Biological aspect of bullet tuna Auxis rochei (Risso, 1810) in the Makassar Strait, West Sulawesi, Indonesia. Croatian Journal of Fisheries, 77:118-125.

Kurniawan, R., Jatmiko, I., \& Tampubolon, P. A. R. P. (2019). Growth pattern of bullet tuna (Auxis rochei Risso, 1810) in west Sumatera waters. In XVI Annual National Seminar on 2019 Fisheries and Marine Research Results. pp. 191-197.

Ndimele P. E., Kumolu-Johnson, C. A., Aladetohun, N. F., \& Ayorinde, O. A. (2010). Length-weight relationship, condition factor and dietary composition of Sarotherodon melanotheron, Rüppell, 1852 (Pisces: Cichlidae) in Ologe Lagoon, Lagos, Nigeria. Agriculture and Biology Journal of North America, 4:584-590.
Nisa, A. F. (2018). Kualitas ikan tongkol (Euthynnus affinis) dengan pengawet alami ekstrak daun ciplukan dan variasi lama perendaman (Quality of mackerel tuna (Euthynnus affinis) with natural preservative of ciplukan leaf extract and variation of soaking time). Skripsi/Thesis. Universitas $\mathrm{Mu}-$ hammadiyah Surakarta.

Noegroho, T., Hidayat, T., \& Amri, K. (2013). Some biological aspects of frigate tuna (Auxis thazard), bullet tuna (Auxis rochei), and kawakawa (Euthynnus affinis) in west coasts Sumatera IFMA 572, eastern Indian Ocean. IOTC Third Working Party on Neritic Tuna, 19:1-13.

Noegroho, T., \& Chodrijah, U. (2015). Population parameters and recruitment patterns of tuna tuna (Auxis rochei Risso, 1810) in the waters of west of Sumatera. BAWAL, 3(7):129-136.

Salmarika, Taurusman, A. A., Wisudo, S. H. (2018). Status pengelolaan sumber daya ikan tongkol di Perairan Samudera Hindia berbasis pendaratan pukat cincin di Pelabuhan Perikanan Samudera Lampulo, Aceh: Suatu pendekatan ekosistem. Jurnal Penelitian Perikanan Indonesia, 24(4):263-272.

Setyadji, B., Novianto, D., \& Bahtiar, A. (2013). Size structure of bullet tuna (Auxis rochei Risso, 1810) caught by small scale and industrial purse seine fisheries in Indian ocean-south of Java based on trial scientific observer data. IOTC Third Working Party on Neritic Tuna, 30:1-10.

Tampubolon, P.A.R.P., Novianto, D., Hartaty, H., Kurniawan, R., Setyadji, B., \& Nugraha, B. (2016). Size distribution and reproductive aspects of $A u x$ is spp. from west coast Sumatera, eastern Indian Ocean. IOTC-2016-WPNT06-19. 9 p.

Welcomme, R. L. (1979). Fishery management in large rivers. FAO Fish. Tech. Pap., (194):60 p.

Widodo, A. A., Satria, F., Sadiyah, L., \& Riyanto, J. (2011). Neritic tuna species caught drifting gillnet in Indian Ocean based in Cilacap Indonesia. IOTCFirst Working Party on Neritic Tuna, 21:1-19.

Widodo, A. A., \& Satria, F. (2013). Catch and size of bullet and frigate tuna caught by using drifting gillnet in Indian Ocean of Indonesia based at Cilacap Fishing Port. Indonesian Fisheries Research Journal, 19(2):73-79.

Widodo, A. A., Satria, F., \& Sadiyah, L. (2014). Status of utilization and management of tuna neritic resources in the Indian Ocean, WPP 572 and 573. 
Asrial et al. / JIPK, 13 (1): 1-10

Jurnal Kebijakan Perikanan Indonesia, 6(1):23-

28. 